\title{
Pathways to the Aviation Professoriate: An Investigation into the Attributes and Backgrounds of Professional Pilot Education Faculty
}

\author{
David Carl Ison \\ Rocky Mountain College
}

\begin{abstract}
The purpose of this study was to identify the pathways professional pilot program faculty take to reach their positions. Data were collected through a survey that was distributed via the internet using Survey Monkey. Pathways were defined by investigations into the occupational and educational histories of the faculty. Also, demographic attributes of the faculty were collected to create a comprehensive picture of the faculty. Statistical analysis of the survey data was conducted using SPSS Graduate Pack software. The findings of the study indicate that professional pilot faculty take a range of occupational and educational pathways to reach their positions in aviation higher education. Two primary pathways were identified: the military and the non-military (civilian). Each of these sub-groups had unique attributes and distinctive career paths. Although faculty take two primary, separate paths to the professoriate, all faculty reach their current position with similar levels of academic and flight credentials as well as length of industry experience. Aviation faculty of all types were found to have significant academic and industry qualifications and certifications. In addition, these individuals had extensive aviation experience.
\end{abstract}

\section{INTRODUCTION}

\section{Overview of the Study}

From 1940 to 2008, there has been significant research conducted on higher education faculty in the United States. Studies such as those by Wilson (1942), Finkelstein (1984), and Reybold (2003) have explored the general attributes of the U.S. professoriate. Detailed data on higher education faculty has been collected via the undertaking of the Department of Education through the National Survey of Postsecondary Faculty (NSOPF). Research has also been conducted on postsecondary faculty in specific subject areas (Reybold, 2003; Fleet, Rosser, Zufall, Pratt, Feldman, \& Lemons, 2006) and of particular demographic attributes (Conley, 2005; Cross, 1991). Yet little data exists on higher education faculty who specialize in the training of pilots. The information that is available on professional pilot program faculty has been limited to demographic details. Further, the most current data is more than ten years old (Johnson, 1999). This is problematic because of the growing importance that aviation higher education has assumed within the aerospace industry as the U.S. military, previously a major supplier of aviation professionals, has faced cutbacks while at the same time the industry, in general, has continued to grow (Echaore-McDavid, 2005). Exacerbating this is the need for highly qualified employees to operate and manage ever more complex aviation technologies which require employees with more advanced education (Brown, 2007; Echaore-McDavid, 2005; Hansen \& Oster, 1997; Baty, 1985). In fact, airlines now have a strong preference towards collegeeducated pilots (Brown, 2007; EchaoreMcDavid, 2005).

Clearly, more information on professional pilot program faculty is needed in order to better understand these individuals, where they come from, what types of career and education experiences they bring to higher education, and with this information, to make predictions about future faculty needs and from where such individuals may be drawn.

\section{Purpose of the Study}

The purpose of this study was to determine the occupational and educational histories of individuals who are full-time aviation faculty at four-year University Aviation Association (UAA) member institutions in order to explore the career pathways these persons take to get to the professoriate. 


\section{Research Objective and Research Questions}

The research objective of the study was to determine the career pathways of individuals who are full-time professional pilot education faculty at four-year University Aviation Association (UAA) member institutions. This study sought answers to the following research questions:

1. What are the occupational histories of individuals who have become full-time professional pilot education faculty at four-year UAA member institutions?

2. What are the educational histories of individuals who have become full-time professional pilot education faculty at four-year UAA member institutions?

3. What are the demographic attributes of individuals who have become full-time professional pilot education faculty at four-year UAA member institutions?

\section{Significance of the Study}

This study is of significance to the aviation industry, postsecondary aviation program administrators, professional pilot program faculty, and future aviation professionals. Moreover, organizations such as the University Aviation Association (UAA) and the Aviation Accreditation Board International (AABI) will benefit from an improved understanding of this critical component of aviation higher education. By learning about professional pilot program faculty, stakeholders can better comprehend who they are, where they have come from, and their general traits. With this information, stakeholders can improve their recruitment and retention efforts for such employees. These details will allow administrators and educational organizations to gain insight into the attributes that faculty should have to be competitive providers of quality education. Administrators also can gain the knowledge necessary for general purposes related to management of academic personnel such as understanding how certain faculty fit into the institution as a whole, as well as the types of classes that an individual should teach and be qualified to teach.

\section{REVIEW OF LITERATURE}

\section{The Aviation Professoriate: Attributes, Education, and Experience}

Through its expansion, aviation has become a pivotal component of the American economic and transportation infrastructure. Concerns about the supply of qualified pilots are a reality across the globe with many airlines having to reduce their minimum hiring requirements to staff their flights. Along with the aforementioned changes in the training and education of future pilots, higher education has taken center stage in the development of new aviation professionals (Donoghue, 2008). With such challenges the need for professional pilot educators has become a vital piece of the support structure. Even at the beginning of the military training slowdown, Luedtke (1993) found that "seventy-six percent of the institutions surveyed indicated their programs were growing and were projected to keep growing in the near future” (pp. 70-71). Johnson (1999) later reported that almost 50 percent of institutions were actively hiring, as well. Johnson (1999) found that aviation faculty retirements were projected to become more numerous starting in 2000 and continuing well into the next decade. This ensures the continued growth in need for aviation educators. Both Brown (2007) and Lindseth (1996) identified the critical importance of faculty to program quality. Thus, administrators must be concerned with the attributes, education, and experience of current and future faculty to assure the uninterrupted production of quality graduates.

\section{Aviation Faculty Demographics}

Although there has been no thorough analysis of the attributes of aviation faculty, there are bits and pieces that can be gleaned from the limited literature that does exist. Accounts of the demographics of aviation faculty are scattered among a variety of research studies though this data was always collected as a secondary component of each study and all but one of such studies are more than ten years old. Baty (1985) collected indirect demographic data which showed that faculty ages were concentrated in the 30-39 and 50-59 ranges, with slightly less in the 40-49 range. 
In 1987, NewMyer found that the average age of aviation faculty was 50.4 years and $90 \%$ of these faculty were male. Luedtke (1993) discovered a similar ratio with 212 of 237 faculty, (89.5\%) being male. Johnson (1999) reported the results from his 1998 study of aviation programs which included some demographic information. Of these individuals, $7.1 \%$ were female, while the remaining $91.1 \%$ were male (with 1.8 percent not reported). In 2008, Ison (2008) collected data from 60 baccalaureate institutions which yielded information on 353 full-time aviation faculty members. Of these faculty members, 36 (10.1\%) were female. The average distribution of aviation faculty per school was 5.88 with 5.28 male faculty per school and 0.6 female faculty per school. There is no data available on the ethnic or racial attributes of aviation faculty to date.

\section{Aviation Faculty Educational Backgrounds}

Aviation programs have only recently begun to offer a doctoral degree, however, the generally accepted aviation terminal degree has historically been at the master's level (Embry Riddle Aeronautical University, 2009). In a study by NewMyer (1988), a majority of aviation professionals responded that the master's degree should be "the minimum degree necessary to enter [the] profession, an industry segment or a particular kind of occupation in [the] industry" (p. 33).

Johnson (1997) indicated that only $1.3 \%$ had an associate's degree, $17.3 \%$ had a bachelor's, $42.7 \%$ had a masters, $37.3 \%$ had a doctorate, and $1.3 \%$ reported another type of degree. In what seems to be an emerging trend in desirable credentials, Johnson (1999) stated "[u]nlike many traditional academic fields of study in higher education (e.g., history and philosophy) where the minimum benchmark for prospective faculty members is an earned doctoral degree, the benchmark for the prospective aviation employee is often more demanding [... there is now] a need for aviation faculty members to possess a graduate degree (with greater emphasis on the doctorate) and preferential teaching experience, [in addition to] actual aviation practitioner oriented field experience combined with professional certification credentials” (pp. 31-32).

Also, because of the small number of advanced degree programs in aviation, it is common for aviation faculty to have degrees in areas outside aviation (Kaps, 1995). The findings of Johnson (1999) agree with this observation, as more than $40 \%$ of respondents had received advanced degrees in education. The next largest areas of study in terms of percentage of degree holders were aviation (10.6\%), business (6.6\%), management (5.4\%) and engineering (5.3\%). Other areas of study included sociology, political science, physics, psychology, industrial technology, and then a variety of humanities and sciences (Johnson, 1997).

Aviation faculty also face educational and credential requirements that are directly associated with aviation. The awarding of flight certificates in a collegiate environment (for credit) requires certification under Federal Aviation Regulation (FAR) Part 141: "[A]ll flight and ground instruction is given by FAA certificated flight and ground instructors" (Lindseth, 1996, p. 9). Johnson (1997) reported that $18.7 \%$ of faculty had private pilot certificates, $60 \%$ had commercial certificates, $45.3 \%$ had an instrument rating, and $34.7 \%$ had an airline transport pilot (ATP) certificate, while $12 \%$ reported having no pilot certification. In addition, $57.3 \%$ stated that they had some level of flight instructor certification and 26.7\% reported having a basic ground instructor certification, $40 \%$ had an advanced ground instructor, and $36 \%$ had an instrument ground instructor.

\section{Aviation Faculty Experiential Backgrounds}

Although there appears to be a tremendous amount of variety among aviation faculty experiential backgrounds, there were larger groupings of individuals with similarities that have been identified. Forty-four percent of aviation education professionals reported moving into such positions from the military, $16.8 \%$ of individuals stated that they entered via general aviation, and 6.4\% entered from the airline industry (NewMyer, 1989, 1987). Slightly more than $21 \%$ indicated that their first occupational position was within some 
component of aviation education (NewMyer, 1988). Haul and Johnson (1990) found that a majority of faculty at a prominent professional pilot education institution, Embry-Riddle Aeronautical University, were previously in the military. In addition to aviation experience, Baty (1985) found that the amount of teaching experience desired by aviation programs was up to three years; however the preferred amount of experience was three to five years.

Little additional data exists on the occupational and experiential backgrounds of aviation faculty. Kaps (1995) stated that aviation faculty typically receive training and experience in the industry environment prior to entering academics, though no data is made available on the types of training and/or experience. In another study, $26.8 \%$ of aviation institutional respondents reported that they had at least 16 years of employment experience within aviation education though no consequential data was made available on previous employment (Johnson, 1999). In a Delphi panel analysis of aviation program quality, the consensus of the participating subject matter experts was that aviation faculty should have a diverse mix of industry, military, airline, corporate, and general aviation experience (Brown, 2007). Simply, put aviation program faculty should come from a variety of experiential backgrounds.

\section{Professional Pilot Educator Career Pathways}

There are two primary paths that professional pilot education faculty take to reach their positions in the professoriate. The civilian pathway is that in which an individual gains flight experience outside of the military. The civilian pathway has a plethora of possible subpaths including corporate aviation, airlines, general aviation, and flight instruction. However, within the civilian pathway, individuals attain their flight and ground certifications in a similar manner gradually accumulating higher levels of qualifications (Hansen \& Oster, 1997).

The alternative to the civilian conduit is the military pathway. Within this realm individuals receive their aviation experience through one of the many branches of the military. Of course, in a majority of aviation faculty positions, more than just industry and/or flight experience is necessary. Civilian persons must seek these additional qualifications, namely advanced education, either in sequence following undergraduate education or at some point later in life.

Military officer personnel, however, face unique educational requirements within the service that encourage the completion of a graduate education prior to exiting the service. Therefore it is not a surprise that persons having military backgrounds have been well suited for faculty positions and have typically made up a significant proportion of those individuals in aviation faculty positions (Echaore-McDavid, 2005; Hansen \& Oster, 1997).

\section{METHODOLOGY}

\section{Selection of the Population}

The unit of analysis for this study was the individual professional pilot education faculty member who was full-time and was employed at a four-year University Aviation Association (UAA) member institution within the United States. The purpose of the survey component of the study was to collect data on the entire population of full-time collegiate professional pilot program faculty, therefore no sampling technique was necessary (Gravetter \& Wallnau, 2007).

\section{Instrument}

The instrument for this research was developed through a literature search of survey procedures and online research. This review was supplemented by aviation employment applications and Federal Aviation Administration forms. The initial survey was then evaluated by a panel of experts that included aviation faculty as well as faculty who have significant experience with developing survey instruments. The resultant survey was built in the Survey Monkey online platform and was designed to insure that it was simple, easy to use, and aesthetically pleasing (Van Selm \& Jankowski, 2006; Alreck \& Settle, 2004).

\section{Procedures}

Initially, the most current (April 2008) University Aviation Association (UAA) institutional member listing was referenced to 
identify four-year institutions that offer aviation programs (University Aviation Association, 2008a). Once this list was compiled, it was cross-referenced with the Collegiate Aviation Guide, which provided detailed listings of collegiate aviation programs and the types of degrees that such schools award. Of a total of 101 institutional members, 70 met the criteria for this study (University Aviation Association, 2008b).

Next, the aviation program website of each of these institutions was mined for faculty contact information. Contact data was then entered into an Excel spreadsheet for organization and sorting purposes.

The mining process produced 329 potentially eligible individuals. It was necessary to eliminate persons who were ineligible for inclusion and those who were outside the confines of the study. Thirty-three individuals were identified who had left their positions, were not in teaching positions, or were not professional pilot faculty. An additional three were found to be part-time employees. A preliminary population to which the survey would be administered numbered 293 individuals. Five contacts of mixed media, as recommended by Dillman (2007), were adopted to maximize response rate. Individuals were sent four e-mails. Those persons who did not respond to the electronic inquiries were contacted one last time via U.S. mail and a telephone call.

\section{RESULTS}

\section{Response Rate}

A total of 293 surveys were distributed via email to aviation faculty at four-year, University Aviation Association (UAA) member institutions within the United States. Once it was determined that email blockage issues existed, 102 separate emails were sent that were specially designed to circumvent further filtration. Finally, 75 surveys were distributed via U.S. mail as a follow up to the emailed versions to those who had apparently not responded. A total of 40 phone calls were made to the remaining non-participating individuals. A total of 235 (80.2\%) responses were received, of which 9 (3.1\%) were refusals, resulting in 226 (77.1\%) positive responses. Four (1.4\%) responses were incomplete and omitted resulting in $222(75.8 \%)$ completed responses. Sixteen (5.5\%) were found to be ineligible because they were not full-time or did not have faculty status. An additional 13 (4.4\%) were identified to be ineligible because they were not professional pilot faculty. The final number of eligible, completed responses was 193 (65.8\%) (see Table 1).

The response rate of the survey component of this study was then compared to the response expectations within the research literature. According to the University of Texas at Austin (2007), "[a]cceptable response rates vary by how the survey is administered: Mail: $50 \%$ adequate, $60 \%$ good, $70 \%$ very good; Phone: $80 \%$ good; Email: $40 \%$ average, $50 \%$ good, $60 \%$ very good; Online: 30\% average." Another study by Sheehan (2001) found that among 31 studies using online methods that were evaluated, the average response rate was 36.8 percent. In summary, the response rate for this research was found to be at an acceptable level for meaningful data analysis.

\section{Demographic Data}

Among the 193 usable, eligible responses, 173 $(89.6 \%)$ were male and 16 (8.3\%) were female with an additional four (2.1\%) who chose "prefer not to answer." Most respondents (41 or $21.2 \%)$ reported that they were between the ages of 56 and 60 . The next largest age grouping, numbering 32 (16.6\%) responses, were those aged 61 to 65 . Fifty-two (26.8\%) of faculty were over the age of 60 and $123(63.7 \%)$ were found to be over the age of 50 . Two individuals selected "prefer not to answer" for gender but stated they were aged 46-50 and 51-55 respectively. Table 2 displays a comprehensive listing of the demographic data of the respondents. A majority of respondents, 168 $(87.0 \%)$, indicated that they were solely Caucasian/White. For a complete breakdown of demographic data, see Table 3. 
Table 1. Summary of Response Rate

\begin{tabular}{|l|c|c|}
\hline & Returned & (vs. 293 total sent) \\
\hline & $\mathrm{N}$ & $(\%)$ \\
\hline Total replies & 235 & $(80.2)$ \\
\hline Refusals & 9 & $(3.1)$ \\
\hline Positive responses & 226 & $(77.1)$ \\
\hline Incomplete responses & 4 & $(1.4)$ \\
\hline Complete responses & 222 & $75.8)$ \\
\hline Ineligible responses & 29 & $(9.9)$ \\
\hline Total usable, qualified responses & 193 & $(65.8)$ \\
\hline
\end{tabular}

Table 2. Demographic Data of the Respondents: Age and Gender

\begin{tabular}{|l|c|c|c|c|}
\hline & Female & Male & PNTA* & Total \\
\hline Under 25 & $\mathrm{N}(\%)$ & $\mathrm{N}(\%)$ & $\mathrm{N}(\%)$ & $\mathrm{N}(\%)$ \\
\hline $25-30$ & $0(0.0)$ & $0(0.0)$ & $0(0.0)$ & $0(0.0)$ \\
\hline $31-35$ & $3(1.6)$ & $6(3.1)$ & $0(0.0)$ & $9(4.7)$ \\
\hline $36-40$ & $2(1.0)$ & $3(1.6)$ & $0(0.0)$ & $5(2.6)$ \\
\hline $41-45$ & $3(1.6)$ & $16(8.3)$ & $0(0.0)$ & $19(9.9)$ \\
\hline $46-50$ & $1(0.5)$ & $15(7.8)$ & $0(0.0)$ & $16(8.3)$ \\
\hline $51-55$ & $3(1.6)$ & $13(6.7)$ & $1(0.5)$ & $17(8.8)$ \\
\hline $56-60$ & $3(1.6)$ & $27(13.9)$ & $1(0.5)$ & $31(16.0)$ \\
\hline $61-65$ & $0(0.0)$ & $41(21.2)$ & $0(0.0)$ & $41(21.2)$ \\
\hline Over 65 & $1(0.5)$ & $31(16.1)$ & $0(0.0)$ & $32(16.6)$ \\
\hline PNTA* & $0(0.0)$ & $20(10.4)$ & $0(0.0)$ & $20(10.4)$ \\
\hline Total & $0(0.0)$ & $2(1.0)$ & $2(1.0)$ & $4(2.0)$ \\
\hline
\end{tabular}

* Prefer not to answer

Table 3. Demographic Data of the Respondents: Race/Ethnicity and Gender

\begin{tabular}{|l|c|c|c|c|}
\hline & Female & Male & PNTA* & Total \\
\hline African American/Black & $\mathrm{N}(\%)$ & $\mathrm{N}(\%)$ & $\mathrm{N}(\%)$ & $\mathrm{N}(\%)$ \\
\hline American Indian & $0(0.0)$ & $3(1.6)$ & $0(0.0)$ & $3(1.6)$ \\
\hline Alaska Native & $0(0.0)$ & $0(0.0)$ & $0(0.0)$ & $0(0.0)$ \\
\hline Asian American/Asian & $0(0.0)$ & $0(0.0)$ & $0(0.0)$ & $0(0.0)$ \\
\hline Caucasian/White & $1(0.5)$ & $1(0.5)$ & $0(0.0)$ & $2(1.0)$ \\
\hline Mexican American/Chicano & $14(6.7)$ & $156(80.8)$ & $0(0.0)$ & $168^{* *}(87.0)$ \\
\hline Native Hawaiian & $0(0.0)$ & $3(1.6)$ & $0(0.0)$ & $3(1.6)$ \\
\hline Pacific Islander & $0(0.0)$ & $0(0.0)$ & $0(0.0)$ & $0(0.0)$ \\
\hline Puerto Rican & $0(0.0)$ & $0(0.0)$ & $0(0.0)$ & $0(0.0)$ \\
\hline Other Latino & $0(0.0)$ & $2(1.0)$ & $0(0.0)$ & $2(1.0)$ \\
\hline PNTA* & $0(0.0)$ & $2(1.0)$ & $0(0.0)$ & $2(1.0)$ \\
\hline Other & $1(0.5)$ & $5(2.6)$ & $4(2.1)$ & $10(5.2)$ \\
\hline Multi-Ethnic/Racial & $1(0.5)$ & $1(0.5)$ & $0(0.0)$ & $2(1.0)$ \\
\hline Total & $0(0.0)$ & $1(0.5)$ & $0(0.0)$ & $1(0.5)$ \\
\hline
\end{tabular}

*Prefer not to answer

**One male and one female marked Caucasian/White and Other; those responses were removed from the total so as to delete the effects of double-counting. 


\section{Faculty Rank}

There were approximately equal numbers of tenured (95 or $49.2 \%$ ) faculty versus nontenured (98 or $50.8 \%$ ) faculty. Among the nontenured faculty, $16(8.3 \%)$ indicated that they were not on a tenure track, but their institution did not have a tenure system. Thirty-six (18.7\%) stated that they were not on a tenure track even though their institution had a tenure system. The remaining $46(23.8 \%)$ were on a tenure track but had yet to attain tenure.

The majority of faculty were ranked at the associate professor level (72 or $37.3 \%$ ) with those holding the rank of assistant professor a close second at 67 (34.7\%) individuals. 38 (19.7\%) reported being at the professor level. Four (2.0\%) indicated they were titled as "instructor" and six (3.1\%) were titled "lecturer." One individual (0.5\%) indicated that there were no formal ranks at their institution. Five $(2.6 \%)$ selected "other" with their openended responses as: aviation department chair, dean, associate dean, assistant professor/chief flight instructor, and dean college of aeronautics.

\section{Subject Areas}

Among the 193 usable responses, there were a total of 738 selections made by respondents for the question concerning subject areas taught by individual faculty. Individuals who indicated that they only taught one nonprofessional pilot education subject (e.g. air traffic control) were excluded from the 193 usable responses. Percentages reported here are in terms of the 193 usable responses, as this better reflects the percentage of faculty that teach each subject area. Seventeen (8.8\%) indicated they taught air traffic control and 35 (18.1\%) selected aviation law. Sixty-eight (35.2\%) taught aviation management and three (1.6\%) taught logistics.

Higher numbers of participation were indicated in the "core" pilot knowledge subject areas: 56 (29.0\%) taught aerodynamics, 71 (36.8\%) taught aircraft systems, 91 (47.1\%) taught pilot certification ground schools, 48 (24.8\%) provided instruction in aircraft navigation, 20 (10.3\%) taught avionics/advanced avionics usage, and aviation safety attracted 71 (36.8\%) responses. Another 29 (15.0\%) taught meteorology. A large number of responses were indicated for human and cognitive areas. Human factors was a subject taught by 65 (33.7\%) respondents, crew resource management was taught by 58 (30.1\%), and eight (4.1\%) taught psychology. Airframe/powerplant maintenance was indicated by sixteen (8.3\%) respondents and five (2.6\%) taught avionics maintenance. Seventy-seven (39.9\%) chose "other," although many responses could have possibly been categorized into the answers available in the survey.

\section{Educational backgrounds}

Faculty were queried as to the highest level of education received, the year they received the associated degree, and in what subject area. Among the 193 qualified, usable responses, the largest group (116 or $60.1 \%$ ) had a master's as their highest achieved degree. Forty-three (22.7\%) had a Doctor of Philosophy (Ph.D.) and 17 (8.8\%) had a Doctor of Education (Ed.D.). Nine $(4.7 \%)$ had a first professional degree (such as an M.D. or J.D.) and five (2.6\%) had a bachelor's degree as their highest education level completed. Two (1.0\%) indicated that their highest achievement was an educational specialist degree. One individual $(0.5 \%)$ noted multiple highest degrees at the master's level with individual degrees in public administration, aeronautical science, and business administration with a specialization in aviation. The mean length of time that a respondent has held this highest degree was 16.5 years $(\mathrm{SD}=$ 10.9). The longest length of time indicated was 46 years while the shortest was one year. For a complete breakdown of highest degrees and lower degrees, see Table 4.

A wide range of subject areas were provided by the respondents. For simplicity, major areas of study will be used to condense the findings. Most of the respondents (57 or $29.5 \%$ ) reported that their highest degree was in an education related subject. The next largest group had received their highest degree in an aviation related subject (40 or $20.7 \%$ ). Business was listed by 36 (18.7\%) respondents and engineering followed with 18 (9.3\%). Ten (5.2\%) respondents reported social science/psychology as their highest degree and nine $(4.7 \%)$ reported law. The remainder of 
subject areas were distributed among natural sciences ( 5 or $2.6 \%$ ), public administration ( 5 or $2.6 \%$ ), technological fields (5 or 2.6\%), miscellaneous science/mathematics (3 or $1.6 \%$ ),

Table 4. Degree Levels of Faculty and those that fit into none of these other categories (5 or 2.6\%). For a breakdown of degree areas of study, see Table 5 .

\begin{tabular}{|l|c|c|c|c|}
\hline & Highest Degree & Secondary Degree & $\begin{array}{c}\text { Tertiary } \\
\text { Degree }\end{array}$ & $\begin{array}{c}\text { Total } \\
\text { Degrees }\end{array}$ \\
\hline & $\mathbf{N ~ ( \% )}$ & $\mathbf{N ~ ( \% )}$ & $\mathbf{N ~ ( \% )}$ & $\mathbf{N ~ ( \% )}$ \\
\hline Doctor of Philosophy(Ph.D.) & $43(7.4)$ & $0(0.0)$ & $0(0.0)$ & $43(7.4)$ \\
\hline Doctor of Education(Ed.D.) & $17(3.0)$ & $0(0.0)$ & $0(0.0)$ & $17(3.0)$ \\
\hline First Professional & $9(1.6)$ & $1(0.1)$ & $0(0.0)$ & $10(1.7)$ \\
\hline Master's & $116(20.0)$ & $76(13.4)$ & $13(2.2)$ & $205(35.6)$ \\
\hline Bachelor's & $5(0.9)$ & $110(19.1)$ & $63(11.0)$ & $178(31.0)$ \\
\hline Associate's & $0(0.0)$ & $2(0.3)$ & $16(2.8)$ & $18(3.1)$ \\
\hline Other & $3(0.6)$ & $1(0.1)$ & $2(0.3)$ & $6(1.0)$ \\
\hline None & $0(0.0)$ & $3(0.5)$ & $96(16.7)$ & $99(17.2)$ \\
\hline Total & $193(33.5)$ & $193(33.5)$ & $190(33.0)$ & $576(100)$ \\
\hline
\end{tabular}

Table 5. Areas of Study of Faculty Degrees

\begin{tabular}{|l|c|c|c|c|}
\hline & Highest Degree & Secondary Degree & Tertiary Degree & Total \\
\hline & $\mathbf{N ~ ( \% )}$ & $\mathbf{N ~ ( \% )}$ & $\mathbf{N ~ ( \% )}$ & $\mathbf{N ~ ( \% )}$ \\
\hline Education & $55(11.5)$ & $16(3.3)$ & $7(1.4)$ & $78(16.3)$ \\
\hline Aviation & $39(8.1)$ & $60(12.5)$ & $33(6.9)$ & $132(27.6)$ \\
\hline Business & $36(7.5)$ & $37(7.7)$ & $10(2.1)$ & $83(17.3)$ \\
\hline Engineering & $14(2.9)$ & $17(3.5)$ & $13(2.7)$ & $44(8.4)$ \\
\hline $\begin{array}{l}\text { Social } \\
\text { Science/Psychology }\end{array}$ & $11(2.3)$ & $12(2.5)$ & $12(2.5)$ & $35(7.3)$ \\
\hline Law & $9(1.9)$ & $0(0.0)$ & $0(0.0)$ & $9(1.9)$ \\
\hline Natural Sciences & $5(1.0)$ & $20(4.2)$ & $9(1.9)$ & $34(7.1)$ \\
\hline Public Administration & $4(0.8)$ & $4(0.8)$ & $0(0.0)$ & $8(1.6)$ \\
\hline Technology & $7(1.4)$ & $6(1.3)$ & $1(0.2)$ & $14(2.9)$ \\
\hline Miscellaneous Sci/Math & $4(0.8)$ & $3(0.6)$ & $6(1.3)$ & $13(2.7)$ \\
\hline Other or Multiple & $9(1.9)$ & $15(3.1)$ & $5(1.0)$ & $29(6.1)$ \\
\hline Total & $193(40.3)$ & $190(39.7)$ & $96(20.0)$ & $479(100)$ \\
\hline
\end{tabular}

\section{Occupational backgrounds}

Occupational backgrounds of faculty were investigated by inquiring into their previous employment experiences. One hundred eightysix (96.3\%) of 193 respondents stated they were employed in an occupation prior to working in their current aviation faculty position. Their average length of service for those reporting more than one year within this position (183 or 98.4\%) was 11.8 years $(\mathrm{SD}=9.98)$.

Among those previously employed, 112 (58.0\%) had an aviation related occupation of which 78 (40.4\%) were employed in the role of pilot. Forty-two (21.7\%) reported being in the military prior to taking their current position. Fourteen (7.5\%) stated that they were previously self-employed. The remainder of those employed in non-aviation positions were scattered across occupational interests.

Looking further into the past occupations of the respondents, faculty were asked if they were employed prior to the aforementioned occupation. One hundred twelve (58.0\%) reported previous employment. Their average 
length of service for those reporting more than one year within this position (107 or 95.5\%) was 9.9 years $(\mathrm{SD}=8.81)$. Among those previously employed, 59 (52.7\%) had an aviation-related occupation of which 43 (38.4\%) reported working in a pilot function. Twenty-nine (25.9\%) individuals of the 112 stated that they were in the military at this point in their occupational history.

Faculty also were asked about their length of service in aviation higher education as well as their future plans associated with this field. The average length of experience in aviation higher education was 16.1 years $(S D=10.27$ ) with the longest length being 43 years and the shortest being less than one year. A significant number of faculty (176 or $91.2 \%$ ) reported that they planned to stay in aviation higher education.

\section{Aviation Qualifications}

\section{Federal Aviation Administration Pilot}

\section{Certifications}

Of the 193 usable, qualified responses, 179 (92.7\%) individuals reported that they had Federal Aviation Administration (FAA) pilot certification(s). Overall, the non-duplicated certificate count at the Airline Transport Pilot (ATP) level was 100 (55.9\%). At the Commercial Pilot level, there were 146 faculty $(81.6 \%)$ and those with private pilot certificates numbered 40 (22.3\%). Three (1.7\%) were Student Pilots and one (0.5\%) individual held a Recreational Pilot certificate. See Table 6 for a breakdown of the category and classes of certifications.

\section{Instrument and Type Ratings}

Faculty who reported being instrumentrated numbered 157 (this includes those with ATP certificates) which equates to $87.7 \%$ of those holding pilot certificates and $81.3 \%$ of all faculty. Seventy-one stated that they had aircraft type ratings. In terms of faculty with pilot certificates, $39.6 \%$ had a type rating. Among all faculty, 36.7\% had this additional qualification. Each faculty reporting a type rating had an average of 1.7 types in which they were qualified. Faculty reported having type ratings in a variety of different aircraft including helicopters and large piston, turboprop, and jet airplanes.

\section{Instructor Certificates}

All respondents were directed to questions concerning their certification as flight and/or ground instructors. One hundred fifty-three (78.7\%) reported having such certifications. All respondents who indicated they had an instructor certification noted that they had multiple certificates. Among all faculty members responding to the survey, 39 (20.2\%) had a Basic Ground Instructor certificate, 78 (40.4\%) had an Instrument Ground Instructor certificate, and 96 (49.7\%) had an Advanced Ground Instructor certificate. One hundred thirteen (58.5\%) stated that they held a Certified Flight Instructor (CFI) certificate. Another 103 (53.4\%) noted that they had an Instrument Instructor (CFII) certificate and 94 (48.7\%) had a MultiEngine Instructor (MEI) certificate. Thirty-one (16.0\%) stated they were Gold Seal flight instructors.

Table 6. Federal Aviation Administration Pilot Certifications: Total Responses

\begin{tabular}{|c|c|c|c|c|c|c|c|c|}
\hline & $\begin{array}{l}\text { Single } \\
\text { Engine } \\
\text { Land }\end{array}$ & $\begin{array}{l}\text { Multi } \\
\text { Engine } \\
\text { Land }\end{array}$ & $\begin{array}{c}\text { Single } \\
\text { Engine } \\
\text { Sea }\end{array}$ & $\begin{array}{c}\text { Multi } \\
\text { Engine } \\
\text { Sea }\end{array}$ & $\begin{array}{c}\text { Rotor* } \\
\text { Heli* }\end{array}$ & Glider & Other & Total \\
\hline & N (\%) & N (\%) & N (\%) & N (\%) & N (\%) & N (\%) & N (\%) & N (\%) \\
\hline $\begin{array}{l}\text { Airline } \\
\text { Transport }\end{array}$ & $12(3.2)$ & $87(23.1)$ & $3(0.7)$ & $2(0.5)$ & $5(1.3)$ & $0(0.0)$ & $1(0.2)$ & $110(29.3)$ \\
\hline Commercial & $97(25.8)$ & $68(18.1)$ & $23(6.1)$ & $0(0.0)$ & $23(6.1)$ & $8(2.1)$ & $1(0.2)$ & $220(58.5)$ \\
\hline Private & $29(7.7)$ & $7(1.8)$ & $0(0.0)$ & $0(0.0)$ & $0(0.0)$ & $5(1.3)$ & $1(0.2)$ & 42 (11.2) \\
\hline Recreational & $1(0.2)$ & $0(0.0)$ & $0(0.0)$ & $0(0.0)$ & $0(0.0)$ & $0(0.0)$ & $0(0.0)$ & $1(0.2)$ \\
\hline Student & $3(0.7)$ & $0(0.0)$ & $0(0.0)$ & $0(0.0)$ & $0(0.0)$ & $0(0.0)$ & $0(0.0)$ & $3(0.7)$ \\
\hline Total & $142(37.7)$ & $162(43.0)$ & $26(6.9)$ & $2(0.5)$ & $28(7.4)$ & $13(3.4)$ & $3(0.7)$ & $376(100)$ \\
\hline
\end{tabular}

$*$ Rotor $=$ Rotorcraft, Heli $=$ Helicopter 


\section{Military Service}

One hundred six (54.9\%) of all responses indicated that the faculty member served in the military in some capacity. Of those that stated such affiliation, 58 (54.7\%) served in the Air Force, nineteen (17.9\%) served in the Navy, 23 (21.7\%) were in the Army, six (5.7\%) served in the Marines, and four (3.8\%) were in the Coast Guard. Ninety-four (88.7\%) of those who served in the military stated they had an aviation-related duty or assignment during their time in the armed forces. Within these 94 responses, 47 (50.0\%) described this function as an aircraft pilot duty (an additional two [2.1\%] had nondiscernable duties). When considering the total number of responses from all faculty, this indicates that $24.3 \%$ were military pilots.

\section{Analysis of Findings}

Data extracted from the survey responses were analyzed for relationships using SPSS Graduate Pack 17 software. Descriptive statistics and chi-square tests were utilized to compare and contrast the attributes of military and nonmilitary faculty (Gravetter and Wallnau, 2007, p. 582). In the limited cases that data lent itself to parametric statistical analysis, an independent measures $t$ test was utilized (Gravetter \& Wallnau, 2007, p. 311). A 0.05 alpha level was selected for all tests. This level was selected as no significant financial or policy decisions rest on the findings of this study, however, the researcher wanted an increased level of confidence that no relationships were caused by chance (University of New England, 2000; Gravetter \& Wallnau, 2007).

Analysis of the mean lengths of time that degrees were held at different levels yielded a mean length of time of 11.7 years for doctoral degrees and for first professional degrees it was 15.1 years. Those indicating they had a master's degree held this level of achievement an average of 20.4 years. The mean length of time bachelors' degrees were held was 28.4 years (see Table 7).

An analysis of faculty rank and age was conducted using the cross-tabulation. The largest percentage of faculty was found to be ages 56-
60. The largest concentration of faculty at the professor rank was 61-65 years old. At both the associate and assistant professor levels this highest concentration was at the 56-60 year range. An overwhelming majority of faculty at the professor level were over the age of 46 while faculty at lower ranks had more even distributions among young age groups. See Table 8 for a comprehensive review of faculty rank versus age.

Another age-related factor, age versus the number of years of participation in aviation higher education, was analyzed. Faculty were grouped as over 40 years old and 40 years and younger as well as by length of service which was defined as either more than five years or five years or less in aviation higher education. A chi-square test for independence found that the groupings were in fact statistically dissimilar $\left(X^{2}\right.$ $(1, n=193)=9.945, p=0.002)$. The highest count was found to be in those who reported being over 40 and in aviation higher education for more than five years. Among newer faculty, it was found to be more likely that faculty would be older. Also, even among younger faculty, individuals were more likely to have been in aviation higher education for more than five years.

The relationship between military service and faculty age was evaluated using chi-square analysis. Four responses of "prefer not to answer" were excluded from the analysis. These two sets of data were found to be dependent as a statistically significant relationship was discovered $\left(X^{2}(1, n=189)=34.958, p<0.05\right)$. According to the data, military faculty were most likely to be over the age of 40 .

The potential for a relationship between military service and the number of years of participation in aviation higher education was conducted using chi-square analysis. These two data sets were found to be unrelated $\left(X^{2}(1, n=\right.$ $193)=0.348, p=0.555)$. An evaluation of the potential relationship between military service and subject area of highest degree held by faculty was conducted using chi-square analysis. These two data sets were found to be independent $\left(X^{2}(2, n=193)=2.506, p=0.286\right)$. 
Table 7. Faculty Degrees: Years Held

\begin{tabular}{|l|c|c|c|c|c|}
\hline & N & SD & Lowest & Highest & Mean \\
\hline & & Year(s) Held & Year(s) Held & Year(s) Held & \\
\hline Doctoral Degree & 60 & 8.21 & 1 & 33 & 11.7 \\
\hline First Professional Degree & 9 & 11.64 & 1 & 31 & 15.1 \\
\hline Master's Degree & 205 & 10.79 & 1 & 46 & 20.4 \\
\hline Bachelor's Degree & 178 & 11.45 & 5 & 56 & 28.4 \\
\hline Associate's Degree & 18 & 11.65 & 5 & 55 & 27.1 \\
\hline Other Degree & 6 & 10.54 & 3 & 31 & 13.0 \\
\hline
\end{tabular}

Chi-square analysis was again used to evaluate the independence of military service and highest flight qualifications held. These two data sets were found to be independent $\left(X^{2}\right.$ (2, $n$ $=179)=3.677, p=0.159$ ).

An evaluation of the independence of military service from tenure status was conducted using chi-square analysis. A statistically significant relationship was found between these data sets $\left(X^{2}(1, n=193)=4.410\right.$, $p=0.036)$. A greater percentage of military faculty was not tenured or was not on a tenure track.

The relationship between military service and the highest degree held by faculty respondents was evaluated using chi-square analysis. A statistically significant relationship was detected $\left(X^{2}(2, n=193)=6.378, p=\right.$ 0.041). Across all degree levels, it is more likely to encounter a military faculty member than one who had not served in the armed forces.

Chi-square analysis also was used to determine if there was a relationship between military service and the length of time in current position. There was no statistically significant relationship observed $\left(X^{2}(5, n=193)=2.193, p\right.$ $=0.822$ ).

In comparing the length of time, in years, faculty have participated in aviation higher education, there was no statistically significant difference between those who were previously in the military $(M=16.59, \mathrm{SD}=10.434)$ and those who were not $(\mathrm{M}=15.59, \mathrm{SD}=10.091), t$ (191) $=0.678, p=0.499$ (two-tailed). However, there was a statistically significant difference between the years that have passed since receipt of the highest academic degree awarded between those who had served in the military $(M=19.22$, $\mathrm{SD}=10.466)$ and those who did not $(\mathrm{M}=13.25$, $\mathrm{SD}=10.556), t(191)=3.924, p<0.05$ (twotailed).

An analysis of the consistency among all subject areas taught (excluding those indicated as "other") between those who have served in the military and those with a civilian background was conducted using chi-square analysis. There were no statistically significant differences noted $\left(X^{2}(11, n=651)=17.147, p=0.104\right)$. Within the "core" pilot knowledge subject areas (aerodynamics, pilot certification ground schools, navigation, avionics usage, systems, and aviation safety), there was no statistical significance between those who were in the military and those who were not $\left(X^{2}(4, n=357)\right.$ $=8.449, p=0.076$ ).

\section{Construction of Career Pathways}

Upon the closing of the survey collection and the completion of the interviews, typical pathways that faculty have taken to reach their positions as postsecondary professional pilot educators were constructed. A wide range of the collected data was re-analyzed to identify any patterns or paths including raw survey responses, statistical analysis, and interview responses. "Typical” faculty paths and attributes began to emerge from the data. Two primary tracks were indicated. The first was the civilian track in which faculty never served in the military in any capacity. The second was the military track in which faculty spent a portion of their careers in the armed forces. Most on the military track spent a significant amount of their employment history as military personnel. 
Table 8. Faculty Rank versus Age

\begin{tabular}{|l|c|c|c|c|c|c|c|}
\hline & Professor & Associate & Assistant & Lecturer & Instructor & Other & Total \\
\hline & $\mathbf{N ~ ( \% )}$ & $\mathbf{N ~ ( \% )}$ & $\mathbf{N ~ ( \% )}$ & $\mathbf{N ~ ( \% )}$ & $\mathbf{N ~ ( \% )}$ & $\mathbf{N}(\%)$ & $\mathbf{N}(\%)$ \\
\hline Under 25 & $0(0.0)$ & $0(0.0)$ & $0(0.0)$ & $0(0.0)$ & $0(0.0)$ & $0(0.0)$ & $0(0.0)$ \\
\hline $25-30$ & $0(0.0)$ & $0(0.0)$ & $6(3.1)$ & $1(0.5)$ & $2(1.0)$ & $0(0.0)$ & $9(4.7)$ \\
\hline $31-35$ & $0(0.0)$ & $0(0.0)$ & $3(1.6)$ & $1(0.5)$ & $1(0.5)$ & $0(0.0)$ & $5(2.6)$ \\
\hline $36-40$ & $1(0.5)$ & $9(4.7)$ & $8(4.1)$ & $0(0.0)$ & $1(0.5)$ & $0(0.0)$ & $19(9.8)$ \\
\hline $41-45$ & $0(0.0)$ & $8(4.1)$ & $7(3.6)$ & $0(0.0)$ & $0(0.0)$ & $2(1.0)$ & $17(8.8)$ \\
\hline $46-50$ & $5(2.6)$ & $7(3.6)$ & $5(2.6)$ & $0(0.0)$ & $0(0.0)$ & $0(0.0)$ & $17(8.8)$ \\
\hline $56-55$ & $7(3.6)$ & $13(6.7)$ & $9(4.7)$ & $1(0.5)$ & $0(0.0)$ & $0(0.0)$ & $30(15.5)$ \\
\hline $61-65$ & $8(4.1)$ & $18(9.3)$ & $13(6.7)$ & $0(0.0)$ & $0(0.0)$ & $2(1.0)$ & $41(21.2)$ \\
\hline Over 65 & $10(5.2)$ & $10(5.2)$ & $7(3.6)$ & $3(1.6)$ & $0(0.0)$ & $1(0.5)$ & $31(16.0)$ \\
\hline $\begin{array}{l}\text { Prefer not to } \\
\text { answer }\end{array}$ & $5(2.6)$ & $6(3.1)$ & $9(4.7)$ & $0(0.0)$ & $0(0.0)$ & $0(0.0)$ & $20(10.4)$ \\
\hline Totals & $2(1.0)$ & $1(0.5)$ & $1(0.5)$ & $0(0.0)$ & $0(0.0)$ & $0(0.0)$ & $4(2.1)$ \\
\hline
\end{tabular}

\section{Occupational Pathways}

Occupational pathways were analyzed for flow of faculty from positions previous to their current role. The flows between different job functions were found to be too chaotic to lead to meaningful synthesis. Instead, flows were divided into aviation and non-aviation related categories. Looking backwards in time, 58\% of faculty held an aviation related occupation prior to their current standing in higher education. $38.4 \%$ held a non-aviation occupation, while $3.6 \%$ held no previous job. Among those that reported previous experience in aviation prior to that point, $20.2 \%$ had an aviation-related job function, $14 \%$ had a non-aviation related job function, and $23.3 \%$ had no previous occupation. Among those who reported their most recent job as being non-aviation related, $10.3 \%$ preceded this occupation with an aviation related field, $13.1 \%$ with a non-aviation related field, and $15 \%$ reported no previous occupation.

\section{Educational Pathways}

Educational pathways were created by tracing how faculty progressed through the different levels of education they have achieved. Most faculty with a Ph.D., Ed.D., or first professional degree as their highest academic credential preceded this achievement with a master's degree. Most with the highest degree of master's first had a bachelor's degree. Among secondary degrees, those with masters were most likely to precede this achievement with a bachelor's degree, if they had pursued another degree. Those with a bachelor's were most likely to have received an associate's prior, if they had another degree. Subject areas in which faculty have their highest degree were most likely to be in education, aviation, or business (in descending order of percentages).

\section{Military Faculty Pathways}

The paths that military faculty took to reach their positions in aviation higher education were created by looking backwards from the present. Among all faculty that responded to the survey, $54.9 \%$ served in the military at some point in their career. $48.7 \%$ of faculty served in an aviation-related function while in the military. However, only $17.1 \%$ of faculty went straight from the military into an aviation faculty position. Prior to becoming an aviation faculty member, $15.5 \%$ held some kind of aviationrelated position in the job force, while $22.3 \%$ held non-aviation related positions. A very small number $(6 \%)$ were not employed prior to being in the military (see Figure 1).

\section{Civilian Faculty Pathways}

The paths that civilian faculty took to reach their positions in aviation higher education were created by looking backwards from the present. $42 \%$ of faculty were identified as civilian track individuals prior to taking their current position. Of these individuals, $36.7 \%$ reported being in an aviation-related occupation previously. 3.1\% reported no previous employment and were by 
default identified as civilian track. Looking back another occupational step, $32.1 \%$ reported having no other employment. 9.9\% did report employment, of which persons were equally distributed between aviation and non-aviation occupations (see Figure 2).

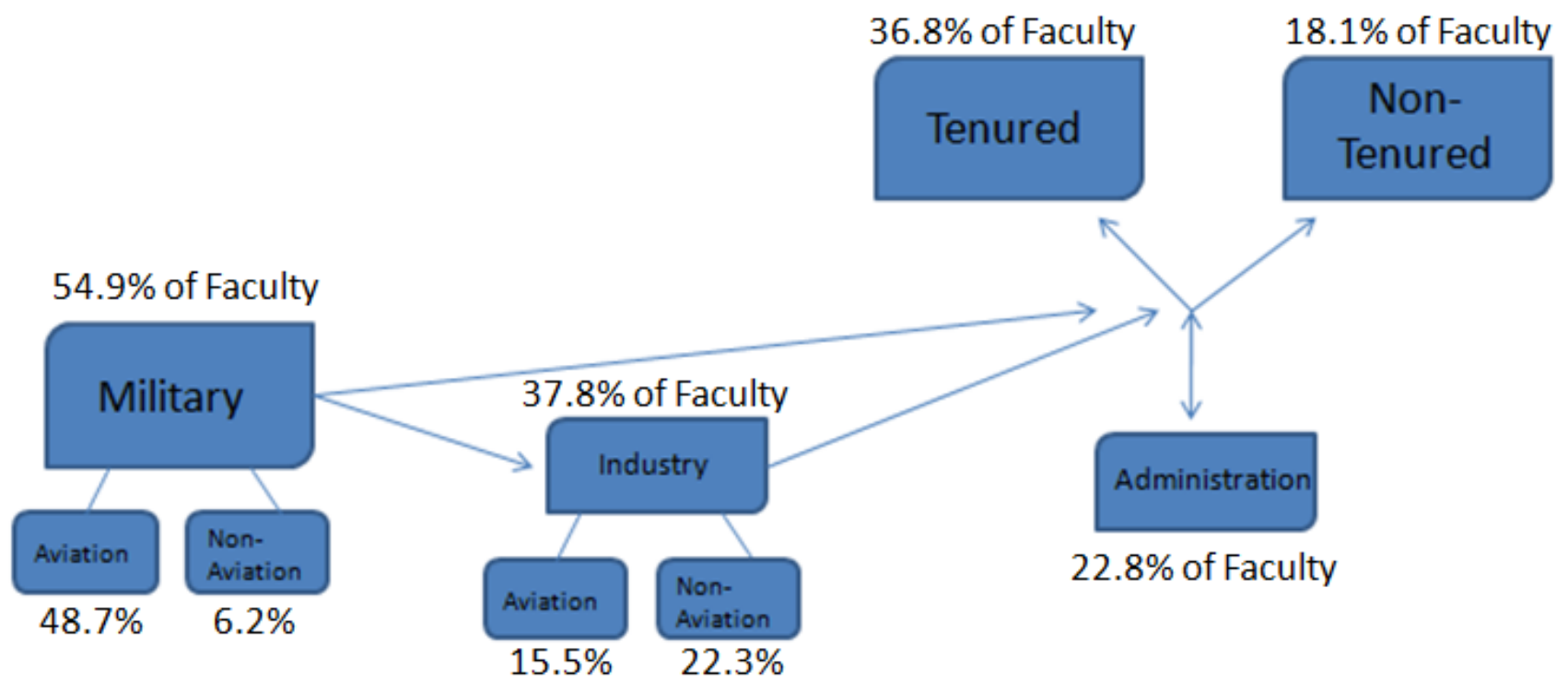

Figure 1. Military Faculty Pathway

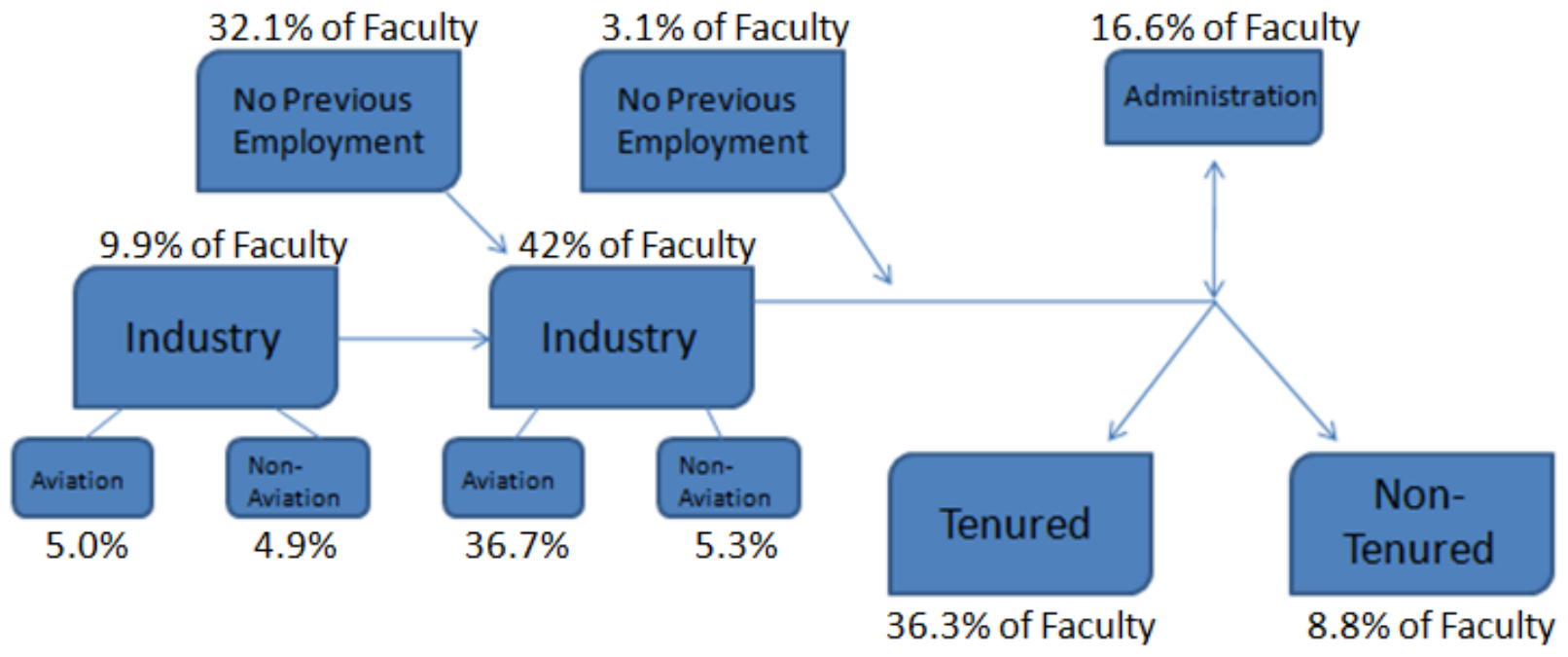

Figure 2. Civilian Faculty Pathway 


\section{SUMMARY AND CONCLUSIONS}

\section{Discussion of Findings}

The survey was able to identify the occupational and educational histories that professional pilot faculty take as they moved through their primary career pathways. This allowed for the construction of two primary methods, the military and the non-military (or civilian); through which faculty reach their positions in aviation higher education. The similarities and the differences between these two groups conveyed characteristic profiles for each, allowing for a better understanding about how faculty in each subset reached their current positions. Further, the demographic attributes of all professional pilot faculty were identified providing an even more comprehensive description of these individuals.

It was noteworthy that there were, in fact, few dissimilarities between the groups. This means that although individuals trace different paths to the same end, they accumulate similar qualifications and skills over equivalent time frames (see Figure 3). The length of service in their current position and in aviation higher education in general was similar for faculty in both pathways. There were no statistically significant differences between the groups in terms of educational and flight qualifications. Also, the subject areas in which faculty taught were also found to be similar.

Although there were many equivalencies between the military and non-military tracks, there were some dissimilarities that were discovered. The most profound of differences among these groups is that of age. Military faculty were more senior than their non-military counterparts. In another item related to the age factor, a statistically significant difference was noted between military and non-military faculty in the length of time since an individual received the highest academic degree. This was not an unexpected finding since military faculty tend to be older, it is therefore more likely that they have received their education further back within their educational history. Finally, military faculty were slightly less likely to be tenured than non-military types.

\section{CONCLUSIONS}

This study successfully identified the pathways professional pilot faculty take to reach positions in aviation higher education. Such detailed information about this group of higher education faculty is of great interest to all stakeholders in the aviation industry because of the vital role these individuals play in the construction of the future pilot workforce in the United States. From this information, higher education and aviation program administrators can develop a better understanding of their employees and what is considered the norm among such faculty at peer institutions. This data was collected through the use of a survey which was designed through an extensive literature review, was evaluated by a panel of experts, and was pilot tested. The majority of responses were collected via an internet-based interface.

In sum, the data provided by this study will be helpful to all types of aviation industry stakeholders, as well as a wide range of persons associated with higher education, as they seek to understand the professional pilot program faculty cohort. Since aviation programs reside within larger, often unrelated components of institutions of higher education (such as schools of engineering or business), it is paramount that the uniqueness of aviation faculty be understood and appreciated at all levels of the institution. 


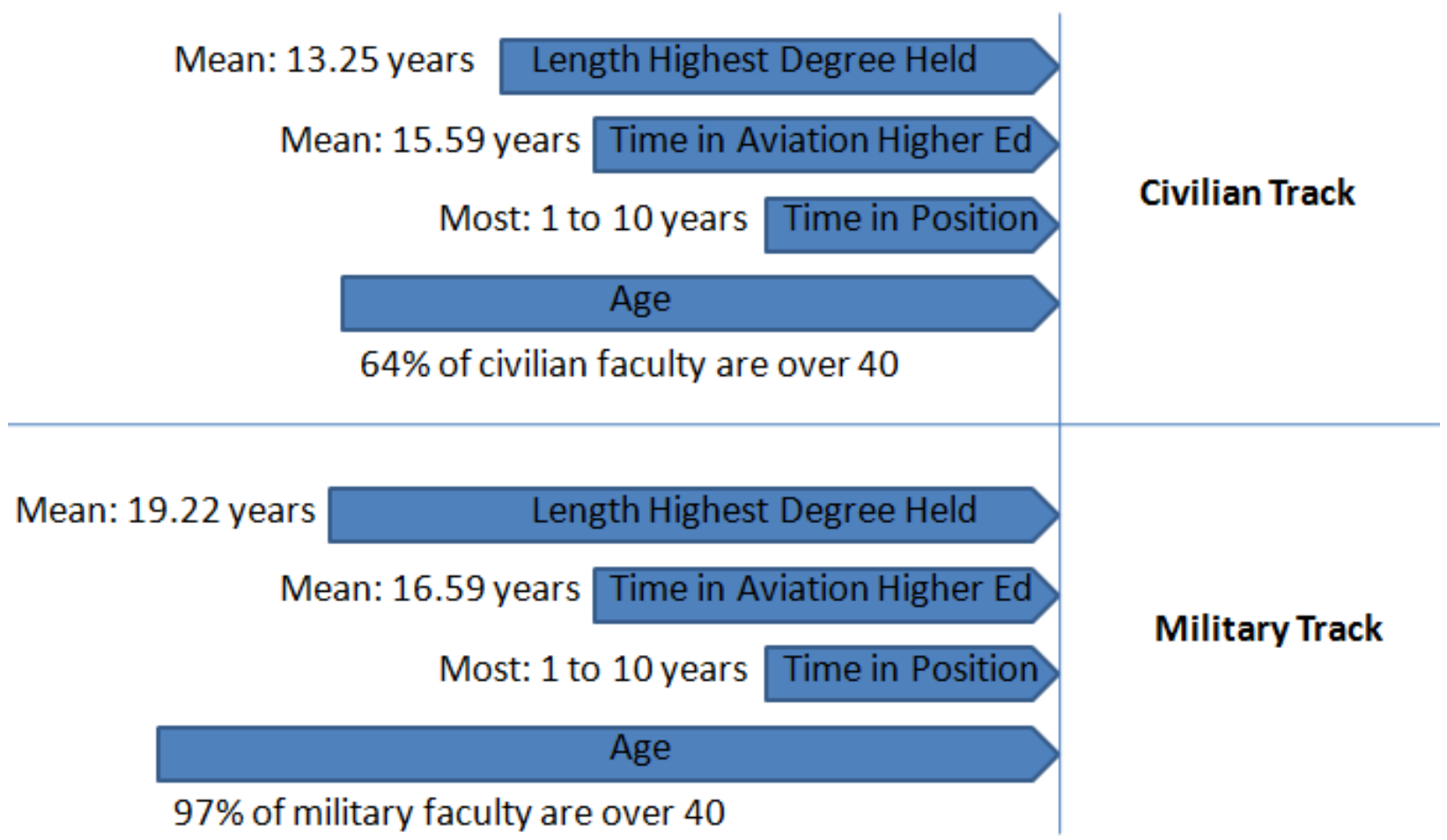

Figure 3. Comparison of the General Chronology of Postsecondary Professional Pilot Educator Careers: Civilian versus Military 


\section{REFERENCES}

Alreck, P. L. \& Settle, R. B. (2004). The survey research handbook (3rd ed.). New York: McGrawHill/Irwin.

Baty, M. J. (1985). Selection criteria requirements and current qualifications of aviation faculty in higher education. (Doctoral dissertation, The University of Tennessee, 1985). Dissertation Abstracts International, 46, 3259.

Brown, D. M. (2007). Quality indicators for collegiate professional pilot training programs: A Delphi study. Ph.D. dissertation, Oklahoma State University, United States -- Oklahoma. Retrieved March 16, 2008, from ProQuest Digital Dissertations database. (Publication No. AAT 3259590).

Conley, V. M. (Summer 2005). Career paths for women faculty: Evidence from NSOPF: 99. New Directions for Higher Education, 130. 25-39.

Cross, W. T. (1991). Pathway to the professoriate: The American Indian faculty pipeline. Journal of American Indian Education, 30(2). 13-24.

Dillman, D. A. (2007). Mail and internet surveys: The tailored design method ( $2^{\text {nd }}$ ed.). Hoboken, NJ: John Wiley and Sons, Inc.

Donoghue, J. A. (2008, June). Training for the pilot shortage. AerosafetyWorld, 3(6), 41-44.

Gravetter, F. J. \& Wallnau, L. B. (2007). Statistics for the behavioral sciences ( $7^{\text {th }}$ ed.). Belmont, CA: Thomson Higher Education.

Johnson, J. A. (1999). An examination of the U.S. collegiate aviation workforce in preparing the next generation aviation faculty members beyond 2000. Collegiate Aviation Review, 17(1). 31-39.

Johnson, J. A. (1997). An analysis of curriculum design in developing a Doctor of Philosophy program in aeronology. (Doctoral dissertation, Bowling Green State University, 1997). Dissertation Abstracts International, 58/08, 3037.

Echaore-McDavid, S. (2005). Career opportunities in aviation and the aerospace industry. New York: Checkmark Books.

Embry Riddle Aeronautical University. (2009). Aviation Ph.D. at Embry Riddle. Retrieved March 10, 2009 from http://aviationphd.erau.edu/

Finkelstein, M. J. (1984). The American academic profession: A synthesis of social scientific inquiry since World War II. Columbus, OH: The Ohio State University Press.

Fleet, C. M., Rosser, M. F., Zufall, R. A., Pratt, M. C., Feldman, T. S., \& Lemons, P. P. (2006). Hiring criteria in biology departments of academic institutions. BioScience, 56 (5). 430-436.

Hansen, J. S., \& Oster, Jr., C. V. (Eds.). (1997). Taking flight: Education and training for aviation careers. Washington, DC: National Academy Press.

Haul, T. L. \& Johnson, J. A. (1990). Recruitment and promotion challenges for aviation faculty in U.S. universities. Journal of Aviation/Aerospace Education and Research, 15(3). 9-10.

Ison, D. C. (2008). The status of women faculty in four-year aviation higher education programs. Journal of Women in Educational Leadership, 6(3). 201-210.

Kaps, R. W. (1995) Perceptions of aviation professionals and aviation educators concerning industrysuggested curriculum content for a non-engineering aviation doctoral degree. Ph.D. dissertation, Southern Illinois University at Carbondale, United States--Illinois. Retrieved March 16, 2008, from ProQuest Digital Dissertations database. (Publication No. AAT 9635017). 
Lindseth, P. D. (1996). Identifying indicators of program quality in United States baccalaureate aviation programs. Ph.D. dissertation, University of Michigan, United States -- Michigan. Retrieved May 11, 2008, from Dissertations \& Theses: A\&I database. (Publication No. AAT 9624672).

Luedtke, Jacqueline R. (1993) Maximizing participation of women in collegiate aviation education. Ed.D. dissertation, Oklahoma State University, United States -- Oklahoma. Retrieved May 12, 2008, from Dissertations \& Theses: A\&I database. (Publication No. AAT 9407262).

Microsoft. (2007). Excel 2007 [computer software]. Redmond, WA: Author

NewMyer, D. A. (1988). Proceedings of the University Aviation Association Conference 1988: A first professional degree for the aviation industry: Recommendations for research and practice. Auburn, AL: University Aviation Association.

NewMyer, D. A. (1987). An analysis of the perceptions of aviation educators concerning non-engineering master's degrees in aviation with implications for a first professional degree (Doctoral dissertation, Southern Illinois University Carbondale, 1987). Dissertation Abstracts International, 49, 442.

Reybold, L. E. (2003, Summer). Pathways to the professorate: The development of faculty identity in education. Innovative Higher Education, 27(4). 235-252.

Sheehan, K. (2001). E-mail survey response rates: A review. Journal of Computer Mediated Communication, 6(2).

SPSS Inc. (2008). SPSS Graduate Pack Version 17 [computer software]. Chicago: Author.

Survey Monkey. (2008). Survey Monkey Survey Platform [computer software]. Portland, OR: Author.

University Aviation Association. (2008a). Institutional members. Auburn, AL: Author.

University Aviation Association. (2008b). Collegiate Aviation Guide. Auburn, AL: Author.

University of New England. (2000). What alpha level? Retrieved January 27, 2009 from http://www.une.edu.au/WebStat/unit_materials/c5_inferential_statistics/what_alha_level.html

University of Texas at Austin. (2007). Response rates. Retrieved January 15, 2009 from http://www.utexas.edu/academic/diia/assessment/iar/teaching/gather/method/survey Response.php

Van Selm, M. \& Jankowski, N. W. (2006). Conducting online surveys. Quality \& Quantity, 40. 435-456.

Wilson, L. (1942). The academic man: A study in the sociology of a profession. New York: Oxford University Press. 